\title{
MODEL SISTEM NAVIGASI INERSIAL: SEBUAH TINJAUAN
}

\section{MODEL OF INERTIAL NAVIGATION SYSTEM: A REVIEW}

\author{
Muhamad $\operatorname{Irfan}^{1 *}$ dan Dwi Haryanto ${ }^{1}$ \\ ${ }^{1}$ Balai Teknologi Survei Kelautan, Badan Pengkajian dan Penerapan Teknologi (BPPT), \\ Jl. MH. Thamrin No.8, Jakarta \\ *E-mail: muhamad.irfan@bppt.go.id
}

\begin{abstract}
ABSTRAK
Sistem navigasi merupakan sistem yang memandu wahana gerak dari satu tempat ke tempat lainnya. Ada banyak sistem navigasi yang digunakan baik untuk kepentingan survei maupun untuk kepentingan umum. Sistem navigasi yang sudah dikenal luas adalah sistem navigasi berbasis satelit menggunakan global navigation satellite system (GNSS) atau global positioning system (GPS). GPS mempunyai kelemahan akibat faktor eksternal yakni sangat tergantung pada perambatan sinyal gelombang elektromagnetik dari satelit GPS ke receiver GPS. Sistem navigasi yang lainnya dan belum banyak dikenal namun sudah banyak digunakan adalah sistem navigasi inersial atau INS (inertial navigation system). INS ini merupakan sistem navigasi yang tidak terpengaruh oleh faktor eksternal, karena dibuat dengan mengikuti hukum gerak Newton, dan terdiri dari sensor accelerometer dan gyroscope. Biasanya INS ini dikombinasikan dengan sistem navigasi GPS untuk mendapatkan informasi navigasi yang lengkap dan akurat, yaitu posisi absolut, percepatan, kecepatan, arah, dan kelabilan (attitude) dengan frekuensi pengambilan data yang tinggi. Tulisan ini membahas tentang model dasar INS dari buku "Inertial Navigation Systems with Geodetic Applications" [Jekeli].
\end{abstract}

Kata kunci: navigasi, accelerometer, gyroscope, inersial, GPS, Kalman filter

\begin{abstract}
[Model of Inertial Navigation System: A Review] Navigation system is a system that guides a moving vehicle from one place to another. There are many navigation systems that are used for survey purposes as well as for public use. One well-known navigation system is a satellite-based navigation system that uses a global navigation satellite system (GNSS) or global positioning system (GPS). GPS has a disadvantage due to external factors that are highly dependent on the propagation of electromagnetic wave signals from GPS satellites to GPS receivers. Another navigation system not so well known but many used is inertial navigation system (INS). This navigation system is not affected by external factors, because this follows Newton's rules and consists of accelerometer and gyroscope sensors. Usually this INS is combined with GPS to get a complete and accurate navigation information that is absolute position, acceleration, velocity, heading, and attitude with high rate frequency data. This paper describes a basic model of INS from the book "Inertial Navigation Systems with Geodetic Applications" [Jekeli].
\end{abstract}

Keywords: navigation, accelerometer, gyroscope, inertial, GPS, Kalman filter

\section{PENDAHULUAN}

Sistem navigasi yang sudah dikenal luas adalah sistem navigasi satelit atau dikenal dengan GPS (global positioning system) atau GNSS (global navigation satellite system)(Farrell and Barth, 1998). Saat ini alat navigasi terpasang pada hampir di setiap smart phone yang sudah dimiliki banyak orang di dunia, sehingga sistem navigasi GPS ini sudah sangat populer. Sistem navigasi lainnya yang juga terpasang pada smart phone adalah sistem navigasi inersial. Sistem navigasi inersial biasanya terkait dengan wahana 
bergerak yang akan memberikan informasi navigasiberupa vektor posisi, kecepatan, arah (heading), dan kelabilan (attitude) (Farrell and Barth, 1998; Jekeli, 2001).

Navigasi merupakan alat bantu pengarah suatu wahana bergerak dari satu lokasi ke lokasi lainnya dengan merujuk pada informasi posisi dan arah dari alat navigasi. Alat navigasi adalah suatu perangkat yang dilengkapi dengan sensor yang dapat memberikan data posisi dan arah geografis di permukaan bumi, sehingga alat navigasi ini diperlukan ketika suatu wahana sedang menempuh perjalanan dari satu tempat ke tempat lainnya. Salah satu alat navigasi yang sudah dikenal luas adalah receiver GPS (Farrell and Barth, 1998; Jekeli, 2001).

Metode penentuan posisi dengan GPS banyak memberikan keuntungan diantaranya menyediakan informasi posisi absolut secara cepat dan teliti tanpa kendala cuaca dan waktu. Namun GPS mempunyai kelemahan yakni sangat tergantung pada perambatan sinyal gelombang elektromagnetik dari satelit GPS ke receiver GPS. Apabila sinyal dari satelit GPS ke receiver GPS tersebut terhalang oleh suatu objek maka sinyal tidak akan sampai pada receiver GPS yang berakibat terhentinya proses penghitungan posisi. Kondisi ini terjadi apabila suatu wahana (seperti mobil) yang terpasang receiver GPS bergerak melintasi terowongan, atau berada di sekitar pepohonan yang rimbun. Untuk kasus receiver GPS yang terpasang pada smart phone, kendala tersebut sudah teratasi dengan adanya metode assisted GPS (A-GPS), yaitu dengan memanfaatkan sinyal GSM yang digunakan pada smart phone untuk memberikan informasi tambahan tentang posisi yang diperoleh dari beberapa stasiun pemancar atau base tranceiver station (BTS), sehingga pada saat receiver GPS berada di area yang tertutup maka informasi posisi masih tetap ada.

Posisi, kecepatan, arah (heading) dan kelabilan (attitude) suatu wahana merupakan informasi penting dalam suatu sistem navigasi. Gambar 1 merupakan ilustrasi dari informasi navigasi yakni posisi, kecepatan, arah (a), dan kelabilan yang terdiri dari roll, pitch, yaw, dan perubahan translasi yang dihasilkannya surge, sway, heave (b). Informasi kelabilan tidak bisa diperoleh hanya dengan sebuah alat receiver GPS, tapi harus dengan minimal tiga buah receiver GPS untuk mendapatkan data spasial dalam 3D (tiga dimensi). Selain itu, kelabilan yang dihitung dengan metode GPS masih tergantung pada kuat lemahnya perambatan sinyal GPS. Oleh karena itu untuk mendapatkan informasi kelabilan secara kontinyu dapat digunakan sistem navigasi alternatif, yakni inertial navigation system (INS) (Farrell and Barth, 1998; Jekeli, 2001).

INS merupakan sistem navigasi yang tidak terpengaruh oleh berbagai faktor eksternal. Sistem navigasi ini berbeda dengan AHRS (Attitude and Heading Reference System), perbedaannya terletak pada fungsinya, yakni AHRS hanya menyediakan informasi kelabilan (attitude) dan orientasi arah (heading) saja, sementara INS menyediakan informasi yang lebih dari AHRS yakni ditambah dengan informasi kecepatan dan posisi.

INS mampu menghasilkan informasi navigasi dengan tingkat kontinyuitas yang tinggi dan frekuensi pengiriman data yang tinggi. Selain itu, INS dapat dikategorikan sebagai sistem navigasi yang mandiri hanya membutuhkan nilai inisialisasi awal sebagai konstanta integrasi. Akan tetapi posisi yang dihasilkan INS mempunyai nilai kesalahan yang selalu bertambah, sehingga terjadi akumulasi kesalahan yang menumpuk. INS terdiri dari sensor yang tidak tergantung pada gelombang elektromagnetik, namun berupa sensor mekanik dengan mengandalkan energi inersial yakni gerakan dari diri sendiri akibat gaya luar yang mempengaruhinya dengan mengikuti hukum gerak Newton. 


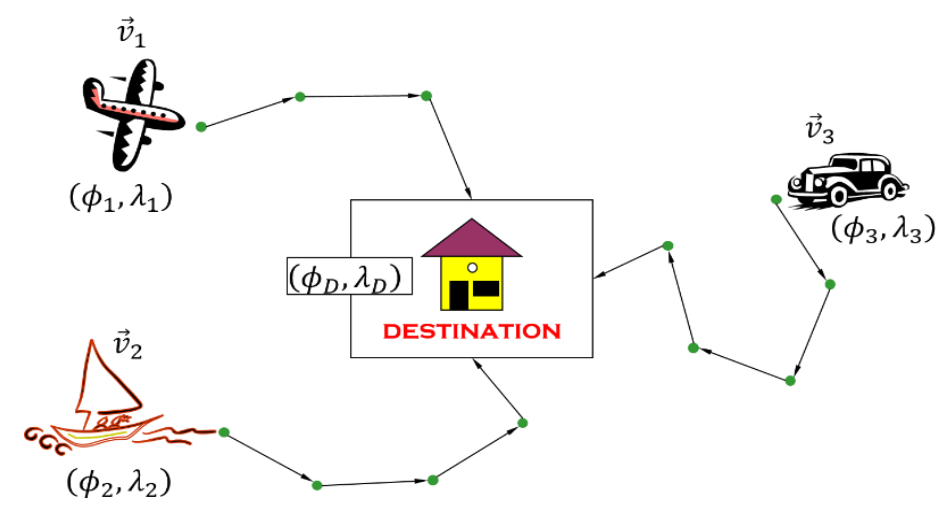

(a)

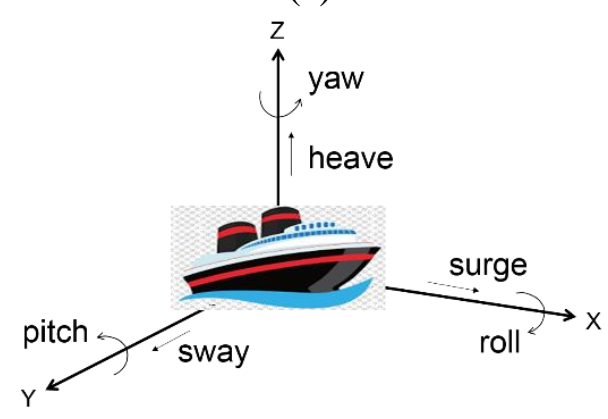

(b)

Gambar 1. Informasi navigasi yang dihasilkan dari suatu sistem navigasi berupa: (a) posisi dan kecepatan, (b) kelabilan.

Tulisan ini bertujuan untuk membahas tentang prinsip dasar sistem navigasi inersial pada wahana bergerak, dengan penekanan pada model matematika. Pembahasannya didasarkan pada buku "Inertial Navigation Systems with Geodetic Applications" (Jekeli, 2001) dan beberapa literatur lainnya (Grewal, 1993; Farrell and Barth, 1998; Salychev and Voronov, 2000). Simulasi data numerik dari model matematika tidak dibahas dalam tulisan ini.

\section{METODE DAN MODEL INERTIAL NAVIGATION SYSTEM}

\subsection{Metode Navigasi}

Secara prinsip, sistem navigasi yang ideal adalah sistem yang dapat menyediakan informasi posisi, kecepatan, arah, dan kelabilan. Dengan berkembangnya teknologi, sistem navigasi dapat dibangun dari beberapa metode yang berbeda untuk menghasilkan sistem yang akurat. Ada beberapa metode navigasi yang sudah dikenal umum, seperti:

- Kompas : metode yang paling sederhana yang menggunakan kompas magnet untuk menunjukkan arah utara

- Astronomi : metode penghitungan posisi dari benda-benda angkasa luar (bintang dan planet) yang tampak, biasanya digunakan oleh para pelaut/nelayan

- Dead Reckoning : metode penentuan posisi dengan mengukur kecepatan dan arah dari suatu wahana bergerak

- Inertial navigation: metode penentuan posisi yang didasarkan pada otomatisasi dead reckoning, dilengkapi dengan accelerometer yang terstabilkan secara otomatis 
- Satellite navigation : metode penentuan posisi dengan mendefinisikan jarak antara satelit dengan alat penerimanya di bumi.

Dari beberapa metode navigasi di atas hanya dua metode yang paling praktis digunakan dengan ketelitian yang baik, relatif terhadap metode lainnya, yakni inertial navigation dan satellite navigation(GPS). Kedua metode ini mempunyai kelebihan dan kekurangan, dan karakteristik dari keduanya dapat dilihat pada Tabel 1.

Tabel 1. Karakteristik dua metode navigasi yang berbeda (Sumber: Jekeli,2001).

\begin{tabular}{|l|l|l|}
\hline \multicolumn{1}{|c|}{ Kriteria } & \multicolumn{1}{c|}{ GPS } & \multicolumn{1}{c|}{ INS } \\
\hline Prinsip pengukuran & Jarak dari beda waktu & $\begin{array}{l}\text { Akselerasi inersial (hukum } \\
\text { Newton) }\end{array}$ \\
\hline Sistem operasi & $\begin{array}{l}\text { Mengandalkan ruang } \\
\text { angkasa }\end{array}$ & Kemandirian (autonomous) \\
\hline $\begin{array}{l}\text { Kesalahan pada periode } \\
\text { panjang }\end{array}$ & Rendah & Tinggi \\
\hline $\begin{array}{l}\text { Kesalahan pada periode } \\
\text { pendek }\end{array}$ & Tinggi & Rendah \\
\hline Frekuensi data & Rendah & Tinggi \\
\hline Harga & Murah & Mahal \\
\hline
\end{tabular}

Prinsip pengukuran GPS berdasarkan pada pengukuran jarak antara satelit GPS dengan antena receiver GPS dari hasil pengukuran beda waktu perambatan gelombang elektromagnetik (Farrell,1998), sementara INS didasarkan pada gerakan inersial yang dihasilkan akibat pengaruh gaya luar. INS akan mengalami kesalahan yang tinggi dalam periode waktu yang lama akibat dari gerakan inersial tersebut, karena kesalahan dari sensor inersial akan bertumpuk dan terakumulasi. GPS sebaliknya, semakin panjang periode waktu pengukuran akan semakin baik hasilnya dengan kesalahan yang rendah. Frekuensi data yang dihasilkan GPS rendah dibandingkan INS yang tinggi, bisa mencapai lebih dari $25 \mathrm{~Hz}$. Namun dengan berkembangnya teknologi, frekuensi data GPS bisa mencapai $10 \mathrm{~Hz}$.

Terlihat dari Tabel 1 di atas, GPS dan INS merupakan 2 metode navigasi yang bersifat komplementer bukan kompetitif. Apabila keduanya diintegrasikan kedalam satu sistem yang terpadu, diharapkan masing-masing kekurangannya akan saling tertutupi oleh kelebihan masing-masing metode, sehingga tercipta suatu sistem navigasi yang kokoh (robust system).

\subsection{Inertial Navigation System}

Berawal dari ide hukum Newton, sistem inersial dikembangkan sejak tahun 1850 pertama kali oleh Jean Foucault yang mendemonstrasikan bagaimana bumi berputar dengan alat yang dinamakan gyroscope (semacam alat pendulum). Maximilian Schuler pada 1923 menyempurnakan alat gyroscopeagar bebas dari pengaruh rotasi bumi, yaitu dengan cara gyroscope tersebut dibuat agar periode osilasi menjadi 84,4 menit (periode Schuler) (Jekeli, 2001). Gyroscope tersebut dikembangkan menjadi gyrocompas yang menjadi alat pertama navigasi inersial (Jekeli,2001).

Secara umum, ada 2 tipe desain INS yaitu tipe gimbal dan tipe strapdown. Tipe gimbal merupakan INS yang sensor-sensornya terpasang pada sebuah platform yang stabil dan terbebas dari gerakan rotasi wahana tempat platform tersebut terpasang. INS gimbal ini merupakan tipe yang cukup akurat dalam menghasilkan data navigasi. Tipe 
strapdown merupakan INS yang sensor-sensornya terpasang langsung ke badan wahana secara terikat (strapped down). Tipe ini lebih murah, ukuran lebih kecil, namun membutuhkan proses komputasi yang cukup kompleks.

INS menghasilkan kesalahan yang besar karena terakumulasi dari kesalahan sensor accelerometer dan gyroscope secara kontinyu. Hal ini merupakan karakteristik utama dari sistem inersial (Tabel 1), terutama pengaruh dari kesalahan gyroscope yang bersifat drifting (tidak bisa dihilangkan secara sistematik). Tabel 2 merupakan pengelompokan nilai deviasi akibat kesalahan drifting INS, semakin tinggi ketelitiannya akan semakin mahal biaya pembuatannya.

Tabel 2. Kategori ketelitian INS (Sumber: Jekeli,2001).

\begin{tabular}{|l|c|}
\hline \multicolumn{1}{|c|}{ Ketelitian } & Nilai Deviasi \\
\hline Rendah & $>2-4 \mathrm{~km} / \mathrm{jam}$ \\
\hline Medium & $1-4 \mathrm{~km} / \mathrm{jam}$ \\
\hline Tinggi & $0.2-0.4 \mathrm{~km} / \mathrm{jam}$ \\
\hline
\end{tabular}

\subsubsection{Konsep Dasar}

Sistem inersial didefinisikan sebagai sistem yang didalamnya berlaku hukum Newton, yang berbunyi:

- Hukum gerak pertama: sebuah benda yang berada di suatu sistem dalam keadaan diam (bergerak lurus beraturan) akan cenderung untuk diam (bergerak lurus beraturan) selama tidak ada gaya yang bekerja terhadap benda tersebut. Untuk memformulasikan sistem inersial ini diperlukan persamaan gerak dinamik berdasarkan hukum gerak kedua dan ketiga Newton.

- Hukum gerak kedua: percepatan suatu partikel massa sama dengan gaya yang bekerja terhadap partikel tersebut. Hukum ini dapat diformulasikan kedalam model matematika.

Model sistem inersial yang menerapkan hukum Newton tersebut adalah accelerometer dan gyroscope, masing-masing berfungsi sebagai sensor untuk mengukur gerakan translasi, dan sebagai alat ukur gerakan rotasi. Kedua sensor ini merupakan sensor mekanik dan tidak tergantung pada gelombang elektromagnetik, tapi merubah gerakan inersial dari dirinya sendiri menjadi informasi navigasi. Ilustrasi dari INS adalah seperti pada Gambar 2, terdiri dari 3 sensor accelerometer, 3 sensor gyroscope, dan alat bantu hitung komputer. INS sangat tergantung dari komputer sebagai pengolah data navigasi, karena model matematika INS yang cukup kompleks dan rumit sangat membutuhkan perhitungan yang cepat.

Prinsip dasar accelerometer adalah pergerakan pegas yang dapat mendeteksi gerakan sekecil apapun apabila dipengaruhi oleh gaya luar. Gerakan pegas tersebut dipasang di 3 sumbu pada sistem koordinat lokal, sehingga akan diperoleh 3 besaran vektor percepatan (acceleration) dari 3 arah.

Gambar 3 memperlihatkan sensor accelerometer yang mengukur gerakan translasi berdasarkan gerakan mekanik pegas dari posisi stabil (a), dan akan memberikan respon jika ada gaya $F$ yang mempengaruhinya (b), sehingga terjadi pergeseran sebesar $x$. Berdasarkan persamaan (1), percepatan benda tersebut dapat diketahui, selanjutnya kecepatan dan posisi dapat dihitung. 


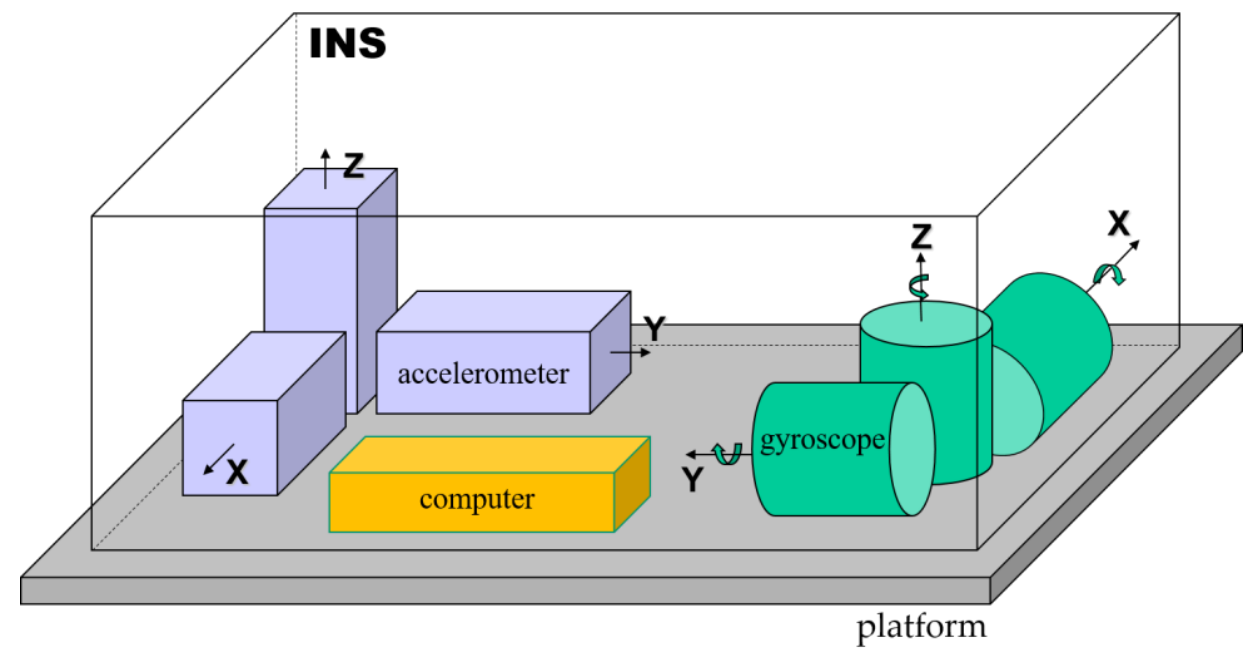

Gambar 2. Konsep dasar INS (Sumber: Jekeli,2001).

(a)
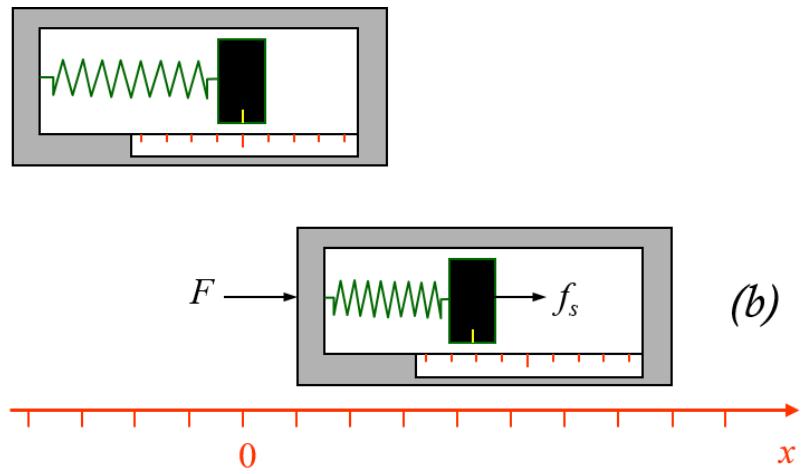

Gambar 3. Sensor accelerometer untuk mengukur percepatan (Sumber: Jekeli,2001).

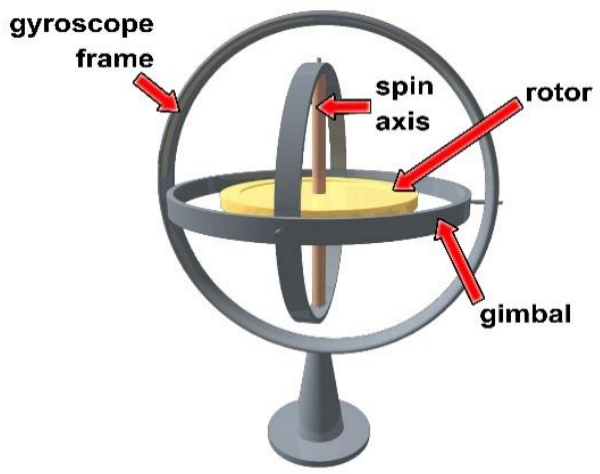

Gambar 4. Sensor Gyroscope (Sumber: Anonim, https://electricalfundablog.com/gyroscope).

Sensor gyroscope digunakan untuk mendeteksi gerakan angular suatu benda apabila ada gaya luar yang mempengaruhinya. Gyroscope dilengkapi dengan rotor yang terpasang pada gimbal yang dapat bergerak dalam 3 sumbu rotasi (Gambar 4Gambar). Pergerakan rotor yang bebas mempengaruhi gerakan gimbal yang terikat pada frame 
yang tetap. Gerakan rotor dipengaruhi oleh gaya yang disebabkan gerakan platform tempat frame diikat secara permanen. Informasi yang diperoleh dari gerakan rotor ini berupa sudut angular yang disebut roll, pitch, yaw.

\subsubsection{Bidang Referensi}

Bidang referensi pada sistem navigasi inersial cukup kompleks karena bidang tempat sensor berada berbeda dengan bidang pada saat informasi navigasi (posisi geografis) dihasilkan. Bidang referensi yang dimaksud adalah sistem koordinat 3 dimensi atau identik dengan sistem koordinat kartesian. Akibat adanya perbedaan bidang referensi, maka dibutuhkan proses transformasi antar sistem koordinat. Bidang referensi yang terkait dengan sistem navigasi inersial terdiri dari:

- Bidang inersial, yaitu bidang tempat berlakunya hukum gerak Newton dimana sensor-sensor inersial terpasang, seperti IMU (inertial measurement units)

- Bidang ECEF (earth-centered earth-fixed), yaitu bidang dengan titik pusat sistem koordinatnya berada di pusat bumi, sumbu-z berimpit dengan sumbu putar bumi, sumbu-x berimpit dengan arah meridian Greenwich, dan sumbu-y berada tegak lurus dengan sumbu-x dengan arah mengikuti aturan putaran tangan kanan

- Bidang navigasi, yaitu bidang dengan sistem koordinat lokal dengan sumbu-x berupa arah utara, sumbu-y arah timur, dan sumbu-z arah ke pusat bumi mengikuti garis gaya berat

- Bidang wahana (body), yaitu bidang tempat IMU diletakkan dengan sumbu-x terdefinisi sebagai arah ke depan, sumbu-z arah ke bawah, dan sumbu-y tegak lurus sumbu-x dengan aturan putaran tangan kanan, serta titik pusat sistem koordinat berada di pusat gravitasi wahana.

\subsubsection{Transformasi Antar Bidang Referensi}

Terdapat beberapa kemungkinan transformasi antar bidang referensi tergantung dari pendefinisan bidang hitung yang akan digunakan. Transformasi akan mudah dihitung apabila orientasi relatif antar bidang sudah diketahui. Besaran orientasi dinyatakan dalam sudut kelabilan (attitude). Terdapat beberapa metode transformasi untuk menentukan parameter kelabilan, yaitu:

- DCM (direction cosines matrix)

Jika ada 2 sistem koordinat yang berbeda maka masing-masing diwakili dengan matriks:

$$
x^{s}=\left(\begin{array}{l}
x_{1}^{s} \\
x_{2}^{s} \\
x_{3}^{s}
\end{array}\right) ; x^{t}=\left(\begin{array}{l}
x_{1}^{t} \\
x_{2}^{t} \\
x_{3}^{t}
\end{array}\right)
$$

Hubungan kedua sistem koordinat tersebut adalah:

$$
x^{s}=C_{t}^{s} x^{t}
$$




$$
C_{t}^{s}=\left(\begin{array}{lll}
c_{11} & c_{12} & c_{13} \\
c_{21} & c_{22} & c_{23} \\
c_{31} & c_{32} & c_{33}
\end{array}\right) \rightarrow \text { matriks transformasi dari bidang-t ke bidang-s (DCM) }
$$

- Euler angles

Metode ini menggunakan sudut orientasi relatif antar 2 bidang yang berbeda dengan besaran yang dinyatakan dengan roll/bank $(\alpha)$, pitch/elevation $(\beta)$, danyaw/heading $(\gamma)$, atau dikenal dengan kelabilan (attitude). Hubungan antara DCM dengan Euler angles adalah:

$$
C_{t}^{s}=R_{3}(\gamma) R_{2}(\beta) R_{1}(\alpha)
$$

$R_{1}, R_{2}, R_{3}$ adalah matriks rotasi dengan sumbu rotasi masing-masing pada sumbu $x$, $y$, $z$. Sedangkan $\alpha, \beta, \gamma$ adalah Euler angles masing-masing sudut rotasi pada sumbu $x, y, z$. Ketiga variabel sudut rotasi tersebut dapat dianalogikan dengan sebuah attitude platform yakni masing-masing sebagai roll, pitch, yaw.

$$
\alpha=\tan ^{-1}\left(\frac{-c_{32}}{c_{33}}\right) ; \beta=\sin ^{-1}\left(c_{31}\right) ; \gamma=\tan ^{-1}\left(\frac{-c_{21}}{c_{11}}\right)
$$

- Quaternion

Metode ini merupakan metode yang didasarkan pada bilangan kompleks yang dinyatakan dengan vektor dalam 4 dimensi yaitu; $q=a+i b+j c+k d$, dimana $a, b, c$, $d$ adalah bilangan real, dan $i, j, k$, adalah bilangan imajiner. Hubungan antara DCM dengan quaternion adalah:

$$
C_{t}^{s}=\left(\begin{array}{ccc}
a^{2}+b^{2}-c^{2}-d^{2} & 2(b c+a d) & 2(b d-a c) \\
2(b c-a d) & a^{2}-b^{2}+c^{2}-d^{2} & 2(c d+a b) \\
2(b d+a c) & 2(c d-a b) & a^{2}-b^{2}-c^{2}+d^{2}
\end{array}\right)
$$

\subsubsection{Hukum Coriolis}

Terkait dengan transformasi antar bidang referensi, ada parameter yang harus diperhitungkan yakni perubahan waktu. Sistem navigasi inersial merupakan sistem yang selalu berubah dengan waktu, dan akan berpengaruh terhadap nilai transformasi yang dihasilkan. Gaspard G. de Coriolis (1792-1843) sudah memberikan solusi penting dengan membuat persamaan hukum Coriolis. Persamaan ini digunakan untuk mendefinisikan perubahan letak bidang terhadap waktu. Persamaan hukum Coriolis adalah: $C_{s}^{t} \dot{x}^{s}=\dot{x}^{t}+\omega_{s t}^{t} \times x^{t}$

\subsubsection{Model Matematika}

Sistem navigasi inersial dibuat berlandaskan pada hukum Newton di atas. Informasi navigasi yang diperoleh dari sistem navigasi tersebut dapatdihitung dengan model matematika yang diformulasikan dengan persamaan berikut. 


$$
F=m \ddot{x}
$$

Persamaan (3) merupakan model dasar untuk penentuan sistem koordinat inersial. Sistem inersial ini dipengaruhi juga oleh gaya gravitasi yang bekerja terhadap benda tersebut. Gaya gravitasi ini dapat berasal dari gravitasi benda itu sendiri seperti planet yang beredar di dalam orbitnya, atau gravitasi dari benda luar yang mempengaruhinya, seperti gravitasi bumi yang mempengaruhi suatu benda di atas permukaan bumi. Sehingga perluasan dari persamaan (3) menjadi:

$$
\ddot{x}=a+g
$$

dimana $a=F / m$, yang merupakan percepatan akibat gaya $F$ terhadap massa $m, \ddot{x}$ adalah percepatan partikel, dan $g$ percepatan gravitasi.

Posisi relatif yang dihasilkan pada persamaan (4) perlu terdefinisi pada bidang hitung tertentu. Bidang hitung ini merupakan sistem koordinat yang menjadi landasan penentuan referensi dalam pengukuran maupun perhitungan, seperti telah dijelaskan di atas.

\subsubsection{Persamaan Navigasi}

Secara prinsip, dalam sistem navigasi inersial, posisi diperoleh dari hasil integrasi percepatan sensor accelerometer terhadap waktu. Integral pertama dari percepatan menghasilkan kecepatan, kemudian integral berikutnya menghasilkan posisi. Dari persamaan (1) dan (4) dapat diturunkan persamaan umum navigasi relatif terhadap bidang sembarang $a$, yaitu:

$$
\begin{aligned}
& \frac{d}{d t} \dot{x}^{a}=-2 \Omega_{i}^{a} \dot{x}^{a}-\left(\dot{\Omega}_{i}^{a}+\Omega_{i}^{a} \Omega_{i}^{a}\right) x^{a}+a^{a}+g^{a} \\
& \frac{d}{d t} x^{a}=\dot{x}^{a}
\end{aligned}
$$

$\Omega_{i}^{a}$ adalah matriks rotasi dari bidang $i$ (inersial) ke bidang $a$ (sembarang).

Bidang atau sistem koordinat yang dipakai pada persamaan (5) adalah bidang sembarang yang bisa diaplikasikan ke bidang yang diinginkan. Apabilabidang sembarang tersebut merupakan bidang navigasi, maka persamaan (5) dapat ditulis dalam bentuk persamaan differential orde pertama di dalam sistem koordinat navigasi sebagai berikut:

$$
\begin{aligned}
& \dot{v}=a+\bar{g}+f_{1} v \\
& \dot{x}=f_{2} v
\end{aligned}
$$

dimana:

$a$ : vektor percepatan dari accelerometer

$\bar{g}$ : vektor gravitasi local 


$$
\begin{aligned}
v & =\left[\begin{array}{lll}
v_{N} & v_{E} & v_{D}
\end{array}\right]^{T} ; x=\left[\begin{array}{lll}
\phi & \lambda & h
\end{array}\right]^{T} \\
f_{1} & =\left(\begin{array}{ccc}
0 & -2 \omega_{e} \sin \phi-\dot{\lambda} \sin \phi & \dot{\phi} \\
2 \omega_{e} \sin \phi+\dot{\lambda} \sin \phi & 0 & 2 \omega_{e} \cos \phi+\dot{\lambda} \cos \phi \\
-\dot{\phi} & -2 \omega_{e} \cos \phi-\dot{\lambda} \cos \phi & 0
\end{array}\right) \\
f_{2} & =\left(\begin{array}{ccc}
\frac{1}{M+h} & 0 & 0 \\
0 & \frac{1}{(N+h) \cos \phi} & 0 \\
0 & 0 & -1
\end{array}\right)
\end{aligned}
$$

Persamaan (6) dan (7) merupakan persamaan free inertial navigation, yang bebas dari berbagai gaya eksternal. Persamaan navigasi ini dapat dipecahkan dengan metode pendekatan numerik untuk menghasilkan nilai posisi dan kecepatan pengamat. Data masukan diperoleh dari sensor accelerometer dan gyroscope yang tergabung dalam satu alat inersial MRU (motion reference unit). Namun persamaan navigasi ini belum memberikan informasi kesalahan hasil pengukuran sensor. Untuk mengetahui sejauh mana pengaruh kesalahan sensor inersial tersebut terhadap solusi navigasi perlu dijelaskan dengan konsep persamaan error dynamics. Model ini dapat memberikan karakteristik perambatan kesalahan dari sensor inersial terhadap nilai yang dihasilkan dari persamaan (6) dan (7).

Model matematik persamaan error dynamics di sistem koordinat navigasi adalah sebagai berikut:

$$
\dot{\varepsilon}=F \varepsilon+G u
$$

dimana:

$$
\begin{aligned}
\underset{(9 \times 1)}{\varepsilon} & =\left(\begin{array}{lllllllll}
\psi_{1} & \psi_{2} & \psi_{3} & \delta \dot{\phi} & \delta \dot{\lambda} & \delta \dot{h} & \delta \phi & \delta \lambda & \delta h
\end{array}\right)^{T} \\
\underset{(9 \times 9)}{F} & =f(a, \phi, \lambda, h, R) \\
\underset{(9 \times 9)}{G} & =f\left(C_{b}^{n}, \phi, R\right)
\end{aligned}
$$

$u$ : system error

$\varepsilon$ : vektor kesalahan sudut orientasi, kecepatan, dan posisi

$F$ : matriks free-inertial dynamics 


\section{PEMBAHASAN}

Persamaan (6) dan (7) merupakan model numerik dasar dari sistem navigasi inersial yang menghasilkan informasi navigasi berupa posisi dan kecepatan. Namun kedua persamaan tersebut masih berupa differential model tingkat pertama yang harus diselesaikan secara numerik. Selain itu juga harus diperhatikan mengenai bidang hitung yang dijadikan referensi, karena implementasi dari sistem navigasi inersial ini terkait dengan beberapa bidang referensi. Akibatnya proses transformasi antar bidang referensi juga harus diperhitungkan secara numerik dengan beberapa alternatif metode.

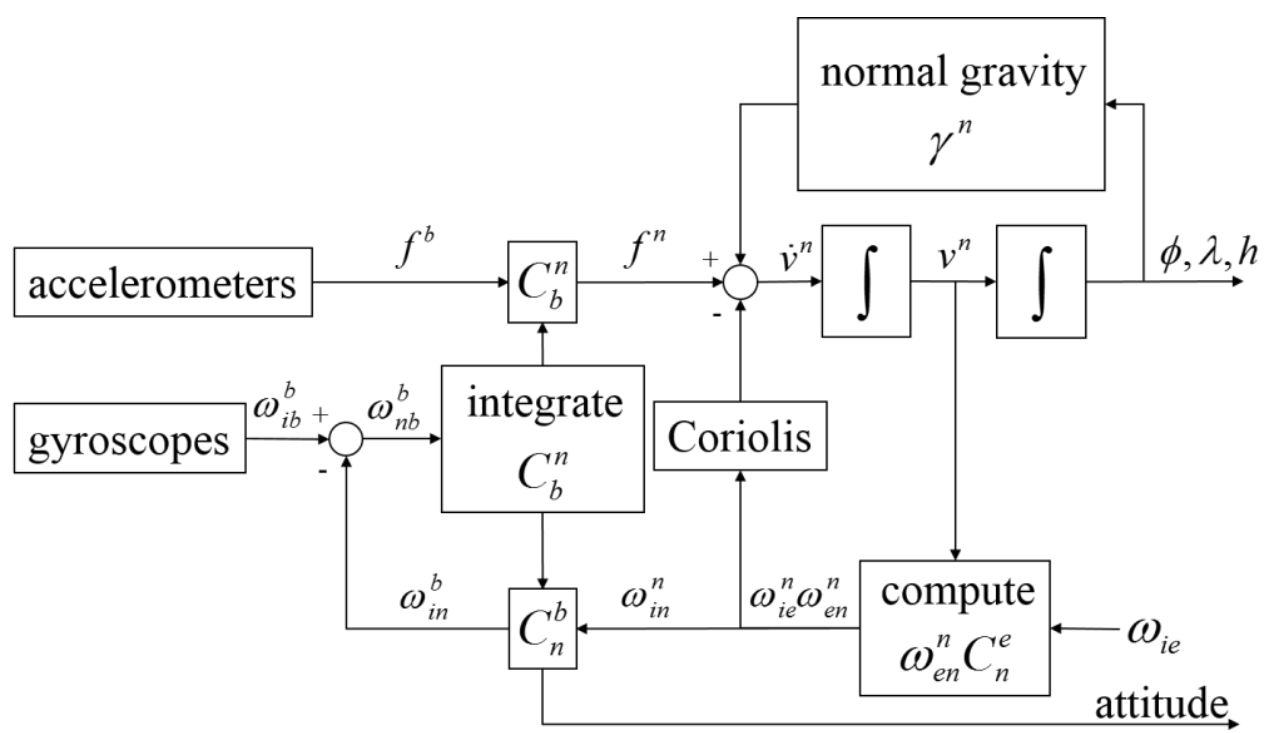

Gambar 5. Algoritma INS pada bidang navigasi (Sumber: Jekeli,2001)

Solusi yang dihasilkan untuk pemecahan persamaan (6) dan (7) sesuai dengan algoritma pada Gambar 5 adalah:

$$
\begin{aligned}
v_{k}^{a} & =v_{k-2}^{a}+\frac{1}{6} \hat{C}_{b}^{a}(k-2) a_{k-2}^{b} \Delta t+\frac{2}{3} \hat{C}_{b}^{a}(k-1) a_{k-1}^{b} \Delta t+\frac{1}{6} \hat{C}_{b}^{a}(k) a_{k}^{b} \Delta t \\
\phi_{k} & =\phi_{k-2}+\frac{\left(v_{N}\right)_{k-1} \Delta t}{M_{k-1}+h_{k-1}} \\
\lambda_{k} & =\lambda_{k-2}+\frac{\left(v_{E}\right)_{k-1} \Delta t}{\left(N_{k-1}+h_{k-1}\right) \cos \phi_{k-1}} \\
h_{k} & =h_{k-2}-\left(v_{D}\right)_{k-1} \Delta t
\end{aligned}
$$

dimana: $N$ dan $M$ adalah jarak sepanjang garis normal ellipsoid bumi.

Persamaan (11) merupakan solusi untuk mendapatkan nilai kecepatan, dan persamaan (12) merupakan solusi untuk mendapatkan nilai posisi di bidang ECEF dengan besaran lintang, bujur, dan ketinggian. Sementara nilai kelabilan dapat diperoleh dari persamaan (2) dengan proses iterasi persamaan (11).

Sistem navigasi inersial sama seperti sistem navigasi lainnya yakni bentuk implementasinya bersifat real-time, dan akan mengalami gangguan dari Gaussian white 
noise, sehingga mengakibatkan data navigasi tidak akurat. Penentuan data navigasi harus bersifat instan sehingga diperlukan model prediksi yang bersifat rekursif, dan nilai yang diperoleh dianggap sudah terbebas dari noise. Hal ini dapat dilakukan dengan Kalman filtering (Gambar 6).

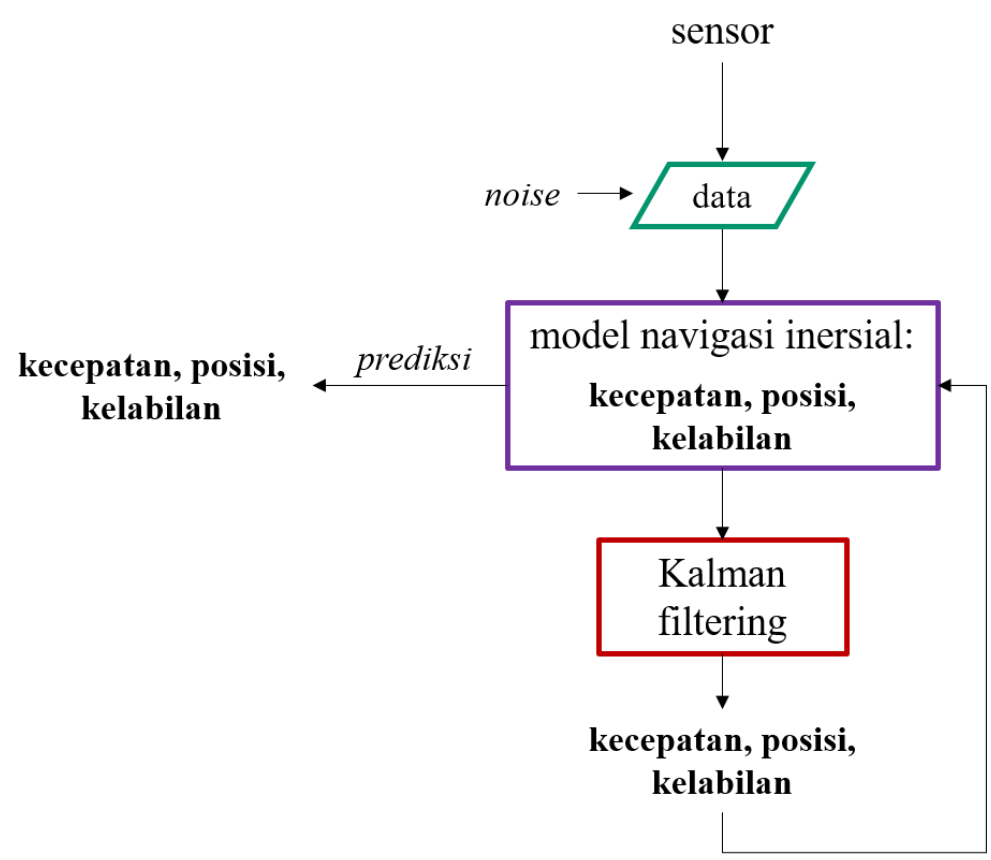

Gambar 6. Kalman Filtering pada sistem navigasi inersial yang real-time.

Kalman filter adalah metode filtering yang dapat menghasilkan nilai estimasi atau prediksi secara instan (real-time) dalam suatu sistem dinamis linear yang mengalami gangguan Gaussian white noise. Dengan kata lain, Kalman filter merupakan algoritma pengolahan data yang bersifat rekursif atau pengolahan yang berulang dengan menggunakan parameter yang sama. Kalman filter menyediakan solusi untuk filtering, prediction, dan smoothing (Grewal, 1993). Secara umum, algoritma Kalman filter dapat dilihat pada Gambar 7.

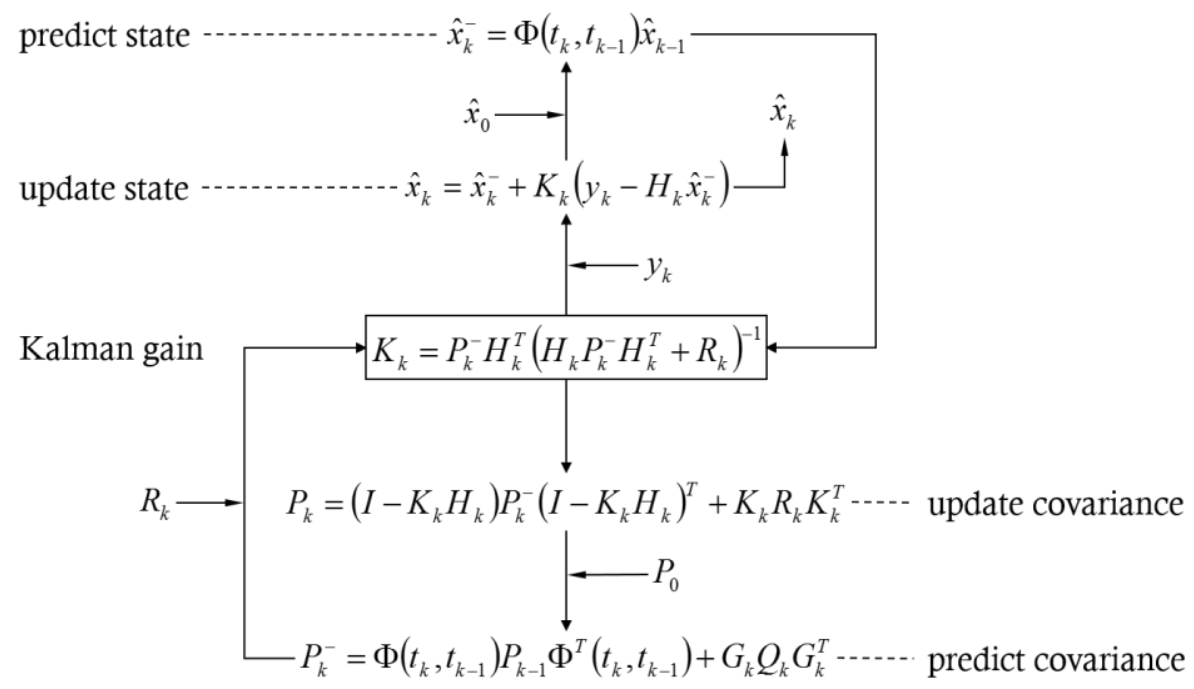

Gambar 7. Algoritma Kalman Filter (Sumber: modifikasi dari Grewal, 1993). 
Filtering adalah proses penentuan estimasi suatu nilai parameter berdasarkan data pengamatan terbaru. Prediction adalah proses penentuan estimasi suatu parameter setelah data pengamatan terakhir. Smoothing adalah proses penentuan estimasi suatu parameter pada setiap waktu berdasarkan data pengamatan keseluruhan yang tersedia.

Sistem navigasi inersial dapat dikombinasikan dengan sistem navigasi yang lain untuk mendapatkan informasi navigasi yang lebih akurat. Kombinasi dengan sistem navigasi satelit akan mendapatkan posisi absolut di permukaan bumi yang akurat dengan frekuensi tinggi. Kombinasi ini biasa disebut dengan sistem navigasi terpadu dengan model Integrated GPS/INS System (Salychev and Voronov, 2000).

\section{KESIMPULAN}

Sistem navigasi yang baik adalah sistem yang dapat menyediakan informasi navigasi secara kontinyu dan akurat. Informasi navigasi yang berguna untuk suatu perjalanan wahana bergerak terdiri dari posisi (position), kecepatan (velocity), dan kelabilan (attitude). Ketiga informasi ini dapat diperoleh dengan sistem navigasi inersial. Sistem ini tidak terpengaruh dengan faktor eksternal karena sistem ini memiliki sensor mekanik yang mengikuti hukum gerak Newton.

Informasi navigasi yang diperoleh dari sistem navigasi inersial merupakan hasil perhitungan numerik dengan mengintegralkan nilai percepatan yang dihasilkan dari sensor akselerometer. Sensor ini terpasang pada suatu bidang inersial sehingga harus diperhitungkan proses transformasi dari bidang tersebut ke bidang navigasi atau bidang bumi. Dengan demikian informasi navigasi tersebut dapat digunakan untuk keperluan navigasi di permukaan bumi.

Untuk kesempurnaan dari implementasi sistem navigasi inersial ini, diperlukan kombinasi dengan sistem navigasi satelit seperti GPS atau GNSS untuk mendapatkan informasi navigasi yang absolut dan terikat di bumi. Kombinasi antara sistem navigasi inersial dan GPS biasa dikenal sebagai integrated inertial navigation system (IINS). Kalman filter berfungsi untuk mengintegrasikan kedua sistem tersebut sehingga diperoleh sistem navigasi inersial terintegrasi yang menghasilkan data navigasi akurat dan kontinyu.

\section{DAFTAR PUSTAKA}

Anonim. (2020). What is Gyroscope - History, Three Degree of Freedom, Basic Properties. https://electricalfundablog.com/gyroscope. Diakses 10 Maret 2020.

Farrell, J.A. and Barth, M. (1998). The Global Positioning System \& Inertial Navigation. Mc Graw Hill, New York.

Grewal, M.S. (1993).Kalman Filtering: Theory \& Practice, Prentice Hall.

Jekeli, C. (2001). Inertial Navigation Systems with Geodetic Applications.Walter deGruyter, Berlin.

Salychev, O.S., and Voronov, V.V. (2000). Low Cost INS/GPS Integration: Concepts and Testing.Proceeding of ION. Anaheim, CA, pp. 98-105. 